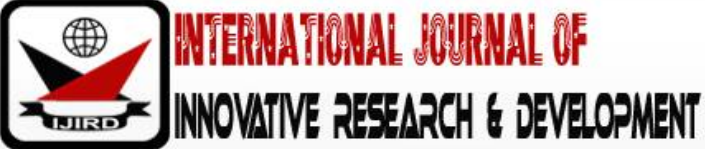

ISSN 2278 - 0211 (Online)

\section{The British, Encounter with the Kibaku People and the Imposition of Colonial Rule in Northern Nigeria}

\author{
Adamu Sani Buba \\ Lecturer, Department of History, University of Malaya, Kuala Lumpur, Malaysia \\ Zulkanain Abdul-Rahman \\ Professor, Department of History, University of Malaya, Kuala Lumpur, Malaysia \\ Azaharudeen Muhammad Dali \\ Associate Professor, Department of History, University of Malaya, Kuala Lumpur, Malaysia
}

\begin{abstract}
:
In 1906, the British sent a military expedition to Kibakul and to bring the people under effective control. The people rose in defence of their independence, using various tactics and strategy. In the process, both suffered some setbacks in terms of men and material. Eventually the people were conquered and brought under British control. When they were conquered and brought under British control, they were ruled in accordance with the indirect rule system. The ruler of the Kibaku ethnic group became a bridge-builder between his subject and the British colonizers. This paper looks at the British campaigns in the Kibakul and between the periods of 1906 to1907. It examines the reason why British sent military expedition against the Kibaku people, a small ethnic group and what factors and strategies adopted in carrying out such campaigns. The introduction of the indirect rule system in Kibakul and and the effects of this alien political system otherwise known as the indirect rule is examined in this article. It concludes that even though the introduction of the indirect rule system in Kibakuland had tremendous negative effects on the people, however, it introduced the people to wider society and helped them to build networks of contacts with people of different background and cultures.
\end{abstract}

Keywords: British, military expedition, colonial rule, Kibau-land northern Nigeria

\section{Introduction}

The European activities in Africa may by explained in terms of changing character of European economies and rapid industrialization which took place in Europe in the late 19th century. D.K. Field house in his book Economics and Empire, 1830-1914 observes that during the second half of the 19th North America modernized their industrial System, along lines, pioneered by Britain, at the beginning, the industries were mainly concerned with import substitution. But they expanded and became increasingly dependent on foreign markets to provide economies of scales. ${ }^{1}$

The dependency on foreign markets by European traders and commercialists to feed their industries, led to open competition amongst them. As Field house observes, "their answer was to use political means to offset the economic disabilities: Ultimately to annex the new markets and surround them with preferential tariffs and other devices for excluding competition" The situation was the revision of Darwinist theory the Survival of the fittest. In Nigeria, there was a serious commercial rivalry amongst Britain, France and Germany. The colonial powers to dislodge one another by signing the so-called commercial treaties with rulers in Nigeria" In fact, in 1893, the competition brought about Britain blocked the French from gaining access the Royal Niger Company, instead, in an Obseassed, by its desire to block the French from gaining access to the Benue River Region British rushed into granting the Germans virtually the entire area of the trust territory of the southern part. Infact, it could be said that the Germans "reaped where they did notsow" the Germans got the whole area on a 'plate of gold' these are land that no German has ever set foot on, such as Madagali, Namoda, Marua, Rai-Buba and Chibok which is our study area, but allowed to operate. As a result, their attempt to dislodge one another saw their commercial agents trying to explore the possibilities of establishing commercial relations with the people of the Benue-River and Lake Chad Basin areas ${ }^{3}$ And therefore, sow Chibok which lay on the Yola-Maiduguri axis as threat to their commercials interest. 


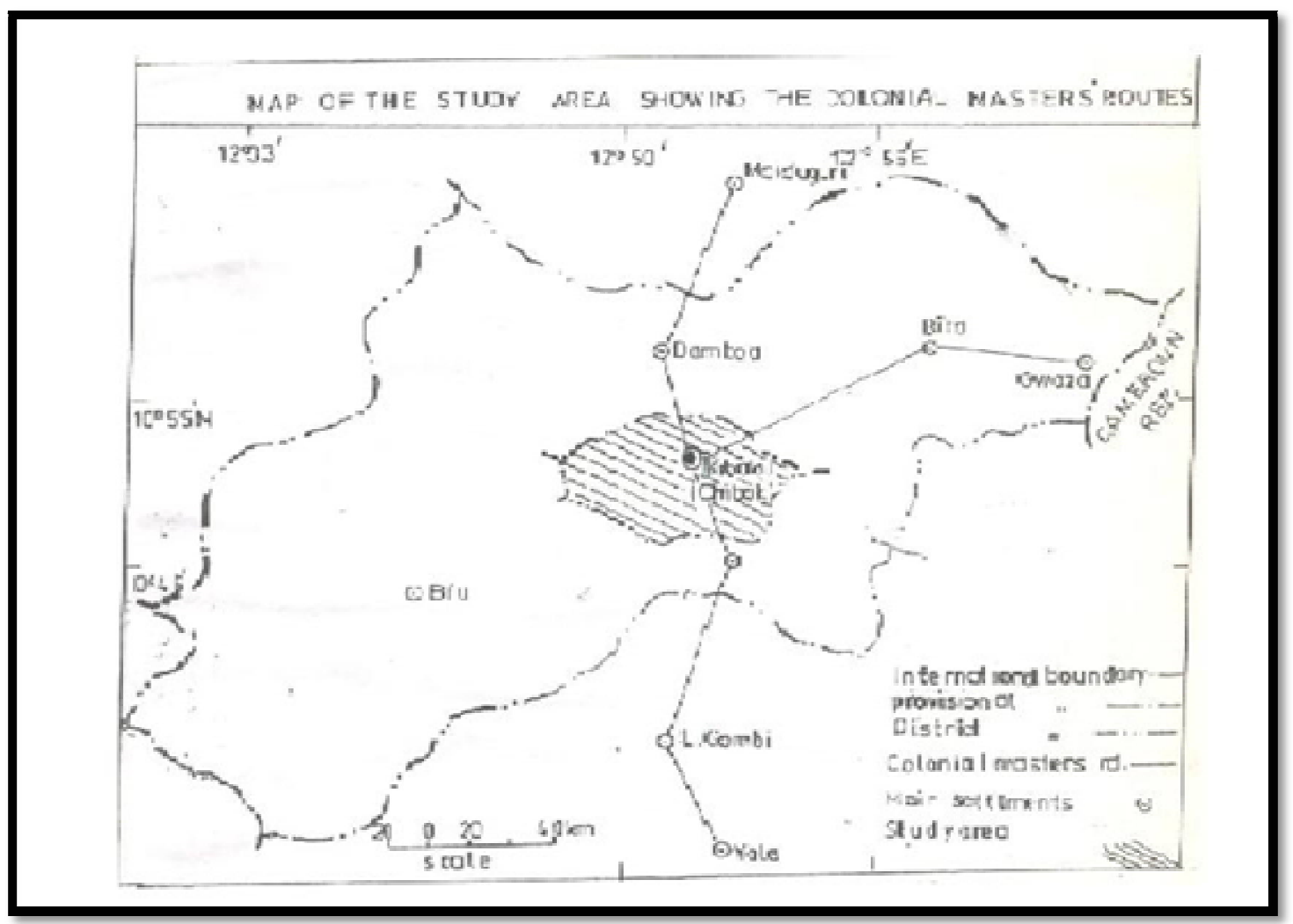

Figure 1

Source: BUBA A.S. The Study of Militarism and Imposition of Colonial Rule (Unpublished M.A Thesis 2007) University of Maiduguri

\section{European Conquest}

The first European to have visited the Kibakuland was Henry Barth, a member of James Richardson expedition to the Lake Chad Basin area. In 1851, Henry Barth was sent from Kukawa in Borno to Adamawa to find out the possibilities of establishing commercial relation with the People of the Emirate ${ }^{1}$. Since Kibaku was cress-crossed by Yola-Borno trade route, it was natural for Henry Barth to pass through Kibaku Villages

On his way to Yola, Barth sow a slave market in Uje, a village not far away from Maiduguri. This village had slaves from the neighboring villages, including slaves from Kibakuland. In talking about the market, Barth says that: There might befrom five to six thousand costumers or slaves, But there would be many more if any security were guaranteed to the visitor from the many independent tribes who were living roundabout, especially the Marghi, Babir and Kere Kere.4

As Barth entered Marghiland, he shows a Bura-like People. His words . . . as the pagan countries in general, seems to inhabited not in Distinct villages and towns where the dwellers stand closely Together but in single forms and hamlets or clusters of hats Each of which contains an entire family spreading over a wide

Expanse of county, each, man's field lying close around his dwelling. ${ }^{5}$

However, it was later discovered that the People Barth saw as Babur-like peoples were actually the Kibaku and the Marghi Peoples;The next European to visit Kibakuland was Mr. Overweigh, one of the European explorers to the Lake Chad Basin, Mr. Overweighs trip to Kibakuland took place in 1851 when he visited Baburland. In the uncompleted journey of his excursion to Fika, he mentioned Kibaku People as kindred of the Babur People. ${ }^{6}$

After 1851, European activities in the upper Benue Valley region and Lake Chad Basin areas, continueto grow steadily,perhaps, the discovery of Benue River which Barth described as "mother" of all rivers must have attracted the attention of European explorers and traders to find out more about scientific and economic potentialities of these regions. The Royal Niger Company that was active in the 19th century tried in Niger- Benue area to extend its commercial activities to the North-Eastern part of the Niger-Benue region.

According to Abubakar Fari: It secured the inclusion of Borno (Bornu) territory south of Barruwa In its sphere of influence by means of the Say-Barruwa line agreement In1890,this was followed by the dispatch of an expedition under the Leadership of its senior executive officer on the Benue River, Macintosh, To Borno(Bornu) to conclude a Protectorate teaty. ${ }^{7}$

The expedition which comprised of an escort of three hundred started its journey from Ribango, very close to Yola, the seat of the Lamido of Adamawa. The expeditionary team, whose destination was Kukawa, had to pass through Kibakuland,on arrival at Kukawa, the expeditionary team was received by Sheikh Hashim, the Shehu of Borno. When the team made its intention known to the Shehu he ordered Macintosh to leave his Empire. As Fari puts again; ... The 
important point is that the expedition reveals a concern on the part of the Company to secure a monopoly of trade which it had previously shared for years. ${ }^{8}$

When British traders were planning to extend their activities to the Lake Chad basin area, the French and the German traders were also doing the same. It was the commercial interest of Germany, France and Britain which helped to bring the latter into prominence in the last decade of the $19^{\text {th }}$ century. However, because in the event of war, amongst them Europe Nations mainly Germany, France and Britain thought t wise to enter into agreement. 9 For example, agreement was concluded in 1890 between Britain and Germany on the one hand and by the former and France on the other. Ironically, this agreement "contributed to rather than diminish the rivalry.9 It is said that:

The accords which left the boundaries to the delighted by Subsequent negotiations (sic) at best allowed the Signatories to jockey for positions. 10

It was in an attempt to interpret these agreements by these European Powers in question that led to rivalries among them.

\section{The Nature of British Military Operation in Kibakuland}

In 1906, the British finally decided to attack the Kibaku people for their refusal to open the trade routes from Maiduguri to Yola which Passed through their land.11 in attacking the Kibaku people, the British did not ignore their past experience with other ethnic groups in Northern Nigeria which they described as "truculent". For example, in 1903, the Waja area which later came to be known as Tangale-Waja Native Authority opposed toBritish presence, in the area, The People of the Lower Gongola basin particularly the Lunguda also attacked British between 1903 and 1906. Therefore, to make Kibaku people accept British authority, they must be forced to give up their independence.

The men that were charged with the responsibility of forcing the Kibaku people to give up their independence were Lieutenant Chapman and Chaytor. ${ }^{12}$ (They also suited the task of compelling the Kibaku to accept British rule in their area). The two men had commanded troops in the British attack on Gujba in Borno 1903. They had also served in the British invasion of Kano in the early 1903. Given their experiences, the two men were once again assigned to command troops against the Kibaku people.

Accordingly, the two men began an aggressive of training men for the task ahead. The men trained so was about one hundred and seventy (170). ${ }^{12} \mathrm{Almost}$ half of the troops were mounted soldiers with the rest as foot soldiers. There were also African carriers who carried machine guns, ammunitions and valuables. The importance of mounted infantry to British conquest of Northern Nigeria, cannot be over emphasized although, this has not been properly documented, by military historians in Nigeria. C.N. Uba, says: Lurgard recognized the need for a mounted unit early enough and its provision was part of his original proposal for the establishment of the West African Frontier force. But the plan could not be executed with success because of the Prevalence of tsetse flies which ensured that practically all horses raised for the purpose died in the raining season which the force men confined to the banks of the Niger. ${ }^{13}$ The rationale behind the use of mounted soldiers in the kibaku encounter was that it would enhance mobility especially in pursuing the mounted force in case the Kibaku had them. Besides, Lieutenant Chapman and Chaytor believed that the mounted soldiers would assist in patrolling the border areas between Chibok and the neighboring villages; the anticipation was that the neighboring villages might give a helping hand to the Kibaku People. Had this happed, the British would have found it difficult to the people under their effective control. However, when the British finally attacked Chibok, the principal town of the Kibaku people, none of the surrounding Villages offered a helping hand. ${ }^{14}$ as regards the weapons at the disposal of the British, the two commanders requested from the Colonial government in Borno one maxim gun and rifles, while on the kibaku side they were well prepared for stiff resistance as we were made to understand, as they had in their arsenal more than300 effective bows and 200 quivers and in addition, 3000 poisoned arrows. ${ }^{16}$ they also had enough food and sufficient water until the next rainy season. Beckley Gall, the resident in Borno puts it: The hill men (Kibaku) has unlimited food, and sufficient water to Last probably until the rains and if, as with more combination Might have appeared from five hundred (500) to one thousand of them are pagans had held to tunnels in this maina Bukar section of The hills and taken no risk, the Northern Nigerian Regiment (NNR) Could not have moved them...15

When the weapons at the disposal of the Kibaku warriors were compared to those of the

British, one would realize that they were no match to that of the British. Needless to say, that the Kibaku Chiefdom was incapable of withstanding the British fire-power. Besides, the Kibaku warriors were never trained in the art of facing an alien force armed with sophisticated weapons. Even though, the number of Kibaku warriors was overwhelming, but in warfare, numbers become important only when other factors such as weapons were equal.

\section{Tactics of War Fear}

In 1904, Borno had come under British effective control. Even though Borno had come under British authority peaceful, yet some ethnic groups in the Chad basin were still opposed to colonial rule. For example, the Kibaku who lived in southern Borno decided to block the trade route from Maiduguri to Yola. To bring the people to order, the British authority in Borno, had to send military expedition to Kibaku land to punish the people. ${ }^{16}$ the finally sent an expeditionary force against the people in 1906. They mounted infantry foot soldiers (both rank and file) left Maiduguri to Chibok through Dam boa. Before they reached Chibok, news had reached the people of the town that the British soldiers were coming to attack them. The people decided to desert their homes for safety. Together with their animals many went into hiding in caves on the mountains hill-top where they inhabit ibid. Many of the caves in the mountains were large enough to contain as many people as possible in fact, the entire population of the village. Besides, the people with enough food that would last for them for one year ${ }^{17}$. 
The British were aware that the terrain was a difficult one; they decided to use foot soldiers as the attacking force, while the mounted soldiers were put to guard all the flanks in case of active support from neighboring villages. Besides, the foot soldiers adopted linear formation, which the linear formation entails soldiers moving in a single file unit until they reach the battle front. ${ }^{18} \mathrm{On}$ the battlefront, the soldiers would quickly move to form "cow-horn formation" before attacking their enemy. Lieutenants Chapman and Chayton, the commanders of the expeditionary force thought that adopting linear and cow-horn formation would easily lead to defeat of the people. However, contrary to the expedition this military tactic proved to be a costly military mistake.

The Kibaku people decided to face the British in their respective tunnels in the hills rather than openly their enemies. In fact, the kibaku adopted guerilla tactics by firing their missiles at the British soldiers only when they made sure that the British soldiers were resting and inactive. In addition to this guerilla tactics, the Kibaku people out a black pot on sticks and sat them out from the caves where their hiding to see whether the British would fire at these pots. On a number of occasions, the British fired at these pots, thinking that the people were coming out of their hiding places to fight. The British soldiers did not know that the Kibaku warriors were simply trying to find out their locations. Once these pots were fired at, the kibaku knew that their enemies were still around. In this case, they would all return to their caves, which had stones as their buffer or covers. The Kibaku continued to face the British using these tactics. To say the least, this tactic worked out well. In the first encounter which lasted for about seven days, the Kibaku put up a strong resistance. 19

It is not surprising that the Kibaku defied the British for seven days. It is said that the people had defied; Borno and Adamawa forces for generations and restricted Fadel-Allah the son Rabe. It is probably, not surprising therefore, that the people resisted the attempt by the British to conquer them at this first phase of their encounter. Extant documentary evidence suggests that about two British Military Officers and ten rank and files were killed in the first encounter. In addition to this, about forty men on the British side severely wounded. Kirk-Greene and Paul Newman report that: The hills men lost probably between (200) and (300) men 20 When the news of the failure of the British to conquer Kibaku was received in Maiduguri, the Assistant Resident in Borno, Captain Both, decided to resort to diplomatic means to bring them to submission. He appealed to the people to lay their weapons and accept British authority over them so that basic and modern amenities such as clean drinking water, good modern roads and other necessities of life would be provided. But, this subtle way of courting their submission was to no avail. ${ }^{21}$

The British, who were determined to conquer the people, began another preparation for the second encounter. Consequently, they decided to look for people that know the Kibaku terrain very well. But unfortunately, it was only the Kibaku people themselves that knew the terrain. Meanwhile, during the first encounter, the British had taken the son of Jatau Ngwakasa's son as hostage. Jatau's son was on his way to Wovi, one of the Kibaku villages famous for its medicine men.Jatau had sent his son to his uncle Hawan Sizau to collect some medicines for him for his illness. It was in the process of going to the village that Jatau's son met expeditionary force on their way to Chibok. Through interrogation, the troops found out that the boy was from Chibok. The soldiers who needed somebody who would direct them to Chibok, decided to take him back to Chibok. When they got to Chibok, Jatau came out to rescue his son when he had him cry loudly. Before Jatau could realize that it was the British who came to invade their land, he was already in their net 22.

Thus, Jatau became the informant to British expeditionary force to Chibok. Therefore, when the British planned to attack Chibok,they took, with them Jatau Ngwakasa and Mai maina, a Chibok man who had been an interpreter to Lord Lugard but had now been transferred to the services of the newly declared Borno Provence. It was after recruiting Jatau and Mai maina in their services that the British sent yet another expeditionary, force against the Kibaku people.

\section{Strategic Plan}

In their strategic plans, the British selected the best and experienced soldiers for the second encounter. The soldiers so selected were put under the command of Lieutenant Wolseley, one of the best and experienced, commanders of that era. With strong force and two interpreters who were themselves from Kibakuland, the British colonial authority in Borno, were optimistic that victory was to be on their side.

The second phase of the operation began when Lieutenant Worsely and his army moved into Chibok in the middle of December, 1906. Specifically, the expedition reached Chibok on 26 th December eighty mounted infantry and ordinary soldiers "to systematically picket all boycott the hills" 23 Captain Worsely and the two Kibaku men in the company of the expeditionary force were the only people so far who knew the wonderful internal formation of the Kibaku hill dwellers. It is pointed out that: Lieutenant Worsely in an attempt to clear the tunnels had One, man killed and twelve wounded. He decided that fully Articles were futile too costly24.

Despite this disaster, Jatau and Mai mama continued to show captain Worsely the caves occupied by each Kibaku clan. It wasalleged that Mai maina told the British soldiers that if they want to succeed in their mission against the Kibaku warriors, commander should station soldiers on 1 lie month of each cave. All the same, the Kibaku warriors did not relent in firing their poisoned arrows from unknown points. Mai maina, one of the kibaku men who revealed the secret of the Kibaku military prowess observed that: One day I went to the mouth of the cave with men W.P Hewby on this occasion,I had a very lucky escape. Mr. W.P. Hewby had told me to call inside to Yalzi Ganaima (sic) that he should come by this exit so that they might discuss terms to end the fighting. I stopped by the mouth of the cave and called Out to Yalzi Ganaima(sic). He said l was listening. I was about to shout Mr. W.P. Hewby's Message to him when somebody shot an arrow at me. I was indeed fortunate that it just missed me.25

The British came to realize that it would be extremely difficult to defeat the Kibaku by merely guarding (lie mount at their caves) while they $\{$ Kibaku $\}$ shot at them from unknown directions. Therefore, Captain Wolseley and W.P. Hewby, the Residents of Borno Province came to believe that a new strategy needed to be worked out before the people could 
submit, to the British expeditionary force. In an attempt to work out new strategy, Captain Wolseley realized that Jatau and Mai maina were not sincere in their dealing of revealing Kibaku military secrets. As would be expected, Captain Worsely called on the two men and told them that if they truly reveal the secret behind the Kibaku prowess, they will be rewarded with political appointments in the British political scheme in Borno Province. There and then he told them that he would want to be appointed chief of his people. While Mai maina, was promised the headship of Damboa ${ }^{27}$.Based on this arrangement, Jatau and Mai maina decided to reveal to Captain Worsely the secret behind the Kibaku resistance and how to overcome them, the following measures should be adopted:

- The Kibaku source of water supply was located somewhere on the mountain should be sealed up if this was done, the people and their animals will starve of water.

- The British should set fire on the kibaku farms and houses to deny the people access to food supply.

- The British soldiers should shoot inside each cave; this will force the people to come out.

With these secrets revealed to the British expeditionary force, Captain Worsely decided to exactly what Jatau and Mai maina had told them. The British started to set the Kibaku houses and farms abbess. They also fired shoot in to the caves after they had sealed up their sources of water supply. After, one and half months of active military engagement with the Kibaku people, the expeditionary forces were able to achieve some success. The Kibaku ran out of food and water after one and half months fighting with the British. The British had experienced just a few of resistance in their military operations in the whole of Northern Nigeria. It was only in 1906, that they experienced again such a glorious revolt in Satiru. In any case, the British finally defeated the people in 1907. Had Jatau and Mai maina not betrayed the Kibaku, the British would have found it difficult to defeat them.28

At the end of the second phase of the campaign, one British officer was killed while twelve rank and file soldiers were severely wounded. As for the kibaku people, they lost (50) men and several them with severe wounds. The British expeditionary force also sized, number of local weapons from the Kibaku fighting force. Arms sized from the Kibaku included one hundred and fifty (150) effective bows, one hundred and seventy (170) quivers and one thousand poisoned arrows. ${ }^{29}$

When Kibaku land fell to the British, the Resident in Borno province, Mr. W.P. Hewby, kept to his promise of giving leadership positions to Jatau and Mai maina. Jatau was immediately appointed the Mai of Chibok. The appointment of Jatau by the British had altered the political equation in Chibok land. Jatau's clan, Nir-Vwa, was said to be not a fullfledged clan, was transformed into one by the British Meanwhile, Mai Maina was appointed as the District Head of Dam boa in 1907. This meant that Jatau would administer Chibok under the leadership of Mai Maina, since Chibok villages were placed under Dam boa District. Mai Maina remained the District head until 1918, when he was removed from office by the British, following his refusal to take instruction from Shehu Garbai, the British Shehu in Yerwa. ${ }^{30}$

\section{The after Mat of the British Military Operation in Kibakuland}

Soon after the defeat of the Kibaku people, the British introduced indirect rule system in the land. Indirect rule as a system meant ruling the "native" people through their chief and institutions. Writing on the indirect rule in Northern Nigeria, Michael Crowder observed that: Indirect rule was a system of colonial administration which not only relied on the indigenous authorities for local government but was constantly guiding to improvement. 30

The agent for the improvement of the system was the British political officer who was always moving and supervising the indigenous rulers appointed by the British colonial government. In this case, Mai maina and Jatau were both been supervised by the British officials in Borno in administering their villages and District respectively? They both served as mouth pieces to the British colonial masters, therefore, were responsible for tax collection from their subjects on behalf, of the colonial government in Borno, they were also in charge in the administration of justice in their respective domain, this was done with the close supervision of the resident and such cases can, only be revised by the colonial government. However, major such criminal cases were referred to the British authority in Borno. The village head of Chibok was allowed to adjudicate cases such as dissolution of marriage, Land maters, in this arrangement, defaulters punished accordingly, while others referred to Damboa for further action. ${ }^{31}$

In introducing the indirect rule in Kibakuland, the Brutish also introduced forced labour in the area. Especially, in the construction of Maiduguri- Damboa road. This caused considerable resentment on the part of the Kibaku people. Besides, the road construction, they were also forced to join the British military as soldiers and carriers. In particular, the carriers conveyed colonial administrators and their goods from one village to another. Some informants still recollect how they carried lag ages of one of the British touring officers from Damboa to Biu, a distance of about ninety-eight kilometers. The demand for carriers during the early days of colonial administration was almost satisfied by the various village heads in Kibakuland. 32

When colonial administration was largely consolidated in kibakuland in about 1912,the people were asked to assist the government in construction of culverts and drainages to link Villages in Damboa district. Apart from this some of the village heads ordered their subject to fetch water and firewood's for the touring officers in the district.

However, the people benefited from the colonial administration in many respect. These benefits came in the form of provision of schools and drinking water. In, 1932, for example, the British built a primary in Chibok to take care of the educational needs of the Damboa district. As would be expected, some of the Kibaku people were able to send their sons and daughters to the Schools and these children were able to learn European way of life. They learnt how to read and write including arithmetic. Thus they became literate. Some of them began to dress in "short knickers and put on sun glasses to show to the villagers they have come of age". Perhaps, this was the beginning of the development in the new ways of life in the Kibaku society. 
There was also significant development recorded in the area of cash economy in Kibakuland. In order to introduce the people to cash economy, the British accordingly introduced taxation system when taxes were introduced, they were told to pay the taxes in British currency, since the people had no means of paying taxes in British currency, the British officials in Borno encouraged them to grow ground nuts and cotton which their traders needed most. So, they grew these crops which were sold at a cheaper rate to the British companies operating in Borno Province.

The indigenous people now used the money obtained from their sells of groundnuts and cotton to pay the taxes. Even though, this system sounds exploitative, in this way, the British were able to introduced cash economy in the area. The introduction of cash economy was detrimental to the Kibaku society. In the first place, it made the people to abandon their food crops to the benefit of the colonial economy. The result was that the much needed food crops such as millet and guinea corn traditionally produced were now neglected. This led relative hunger in the land. And, again, the people developed test for European goods, rather, than their African goods. This also so led to killing of the Kibaku textile industries known for its famous cloth called Bul-gujba worn by men and Gumbara worn by women mostly, during festivities and important occasions. The "Gumbara" was said to be similar to that of the Tiv ethnic group hand- made dress, with white and black strips. While, the "Bul-gujba" is called, "Godo" a thick hand-made gown.

The test for European goods did not only affect Kibakuland and its people. Certainly, the whole of the former trust territory was affected. And Nigeria as a whole begun to realize the implication and danger in abandoning their traditions for alien tradition, the Government of Nigeria has put in place mechanism in making sure that tradition and culture of indigenous people remain uncontaminated, taking drastic measure. On a final note, the Kibaku began to migrate to urban centers such as Maiduguri their state capital and Yola in such for greener posture. The result of this movement, of RuralUrban migration drift, affected the growth of Chibok and Damboa Towns.

\section{Conclusion}

This paper studies the British military operation to Kibakuland. It is pointed out that the British- Kibaku encounter was an unusual experience for the British troops. Yet, the British were able to subdue them and brought them under their effective control. Even though, the Kibaku were defeated by the British troops, the Kibaku warriors had given account of their martial qualities. This was attested to by the Resident in Borno after the fall of the Kibaku people, the British introduced alien system in direct rule of administration in the land. In the process, the Leader of the Kibaku became the mouth piece of the Imperial powers. Not only that, the people was introduced to force labour, new economic system and social way of life. We have seen that the introduction of new political, economic and social systems while beneficial, and yet, detrimental effect to their lives. Today, they had been able to build network of contacts with wider societies and deeply involved in polities of their society.

\section{References}

i. Fieldhouse, D.K. Economics and Emoire, 1830-1914 (London: Oxford Wyman Ltd,

ii. 1973), PP.11-13.

iii. Ibid

iv. Dada, J.P. et al The Kamue (Higi)People of Adamawa State (Kaduna: Apani Publication,

v. 2005), P. 56.

vi. Davies, J. G. The Biu Book (Zaria: Gaskiya Corporation, 1956), P. 38.

vii. Ibid. PP. 38-39.

viii. Ibid. P. 39 .

ix. Ibid

x. Fari, A. A. The Annexation of the Niger Benue Region: A study in Anglo-African Relations

xi. Between1850and 1901, (Unpublished Ph.D.Thesis, University of Liverpool, 1988). PP.355-356.

xii. Ibid. 358.

xiii. Ibid

xiv. Ibid

xv. Ibid

xvi. Uba, C. N. Colonial Military and Society in Northern Nigeria, (Kaduna: Baraka Press,2001),

xvii. P. 260.

xviii. Ndirmbitah, G. Y. A History of the Kibaku, (Kaduna: Baraka Press,2000, P.90.

xix. Beckly, S. G. O. F., Borno Province Annual Report, 1906, PP. 3-6.

xx. Uba, C. N. "The Army of Conquest and Occupation of the Sokoto Caliphate, 1897-1906".

xxi. A Paper Presented at the International Conference on the Europeans at the Sokoto Caliphate,held at Usman Danfodio University, Sokoto, October 22th 2000, P. 4.

xxii. Ndirmbitah, Y. N. A History of the Kibaku, (Kaduna: Baraka Press, 2000), PP. 92-93.

xxiii. Tholison, W. B. Annual Report for Borno Province, 1913, P. 13 NAK.

xxiv. Ikime Obaro, The fall of Nigeria: The British Conquest, Ibadan, Heinemann, P. 24.

xxv. Kirk-Greene, A.H.M and Paul Newman, West African Travels and Adventures (London: Yale

xxvi. University Press, 1971), P. 162.

xxvii. Annual Report on Borno Province for the Year 1906, NAK, ACC. No. 1756, P. 3.

xxviii. Uba, C. N, Colonial Army and Society in Northern Nigeria, (Baraka Press: Kaduna, 1998,) P.91.

xxix. Ibid

xxx. Patrick, J. (ed) Sociology: An Introduction, (Hot-press: New York, 1980). P. 11. 
xxxi. Ukpabi, S. C, Srands in the Nigeria Military History (Gaskiya Corporation, Zaria, 1989).

xxxii. Ndirmbitah, G. Y, A History of the Kibaku People, (Baraka Press: Kaduna,2000).

xxxiii. Ibid

xxxiv. Dagum, L. N," Kibaku and their Neighbours" (Unpublished Dessertation, UniMaid, 1992). P.3

xxxv. Kirk-Greene and Temple, C. L, (Ibid) 1965.

xxxvi. Lurgard, Annual Reports, 1906, NAK, P. 330. 